\title{
Potentials of African Star Apple (Chrysophyllum albidum) Fruit Shell Adsorbent in Recovery of Valuable Hydrocarbons for Spent Engine Oil
}

\author{
Taiwo Elijah ${ }^{1, a^{*}}$, Tokede Oluwatosin ${ }^{1, b}$ and Sanda Olayinka ${ }^{1, c}$ \\ ${ }^{1}$ Department of Chemical Engineering, Faculty of Technology, \\ Obafemi Awolowo University, Ile- Ife \\ aetaiwo@oauife.edu.ng,,tosintokede@gmail.com, ${ }^{\text {'c }}$ tanchemie02@gmail.com,
}

Keywords: Spent engine oil, hydrocarbon recovery, Chrysophyllum albidum shell adsorbent.

\begin{abstract}
Inventory of spent engine oil continuously increase and indiscriminately disposed of at auto-mechanics garages. Adsorptive separation established to be indispensable in recovery of these hydrocarbons was carried out using Chrysophyllum albidum (African star apple) fruit shell - a renewable resource. In this study, clay pretreated spent engine oil was recovered in a fixed bed adsorption processes and the recovered adsorbate components determined by GC-MS analysis. The results showed African star apple fruit shell adsorbent effective in recovering n-hexane solubilized spent lubricating oil. The study concluded that using the developed African star apple fruit shell adsorbent, an agricultural waste adsorbent in the recovery of waste lubricating oil will enhance greatly the nation's economy.
\end{abstract}

\section{Introduction}

Lubricant is a composited organic substance, capable of reducing friction between surfaces, usually metals in physical contact, thereby reducing the heat generated by the motion of the contacting surfaces. Functions of the lubricating oil are; cooling of surfaces when applied, transmitting forces and transporting foreign particles off the contacting surfaces [1]. Thus, lubricating oils play dual function of heat removal and that of friction reduction [1-3]. Lubricating oil from petroleum consists mainly complex mixtures of hydrocarbons. It mostly consists of isoalkanes with slightly longer branches, mono cycloalkanes and mono aromatics with several branches on the ring [2].

The main ingredient of lubricating oil is the base oil, obtained either from crude oil or synthesized. Additives are then mixed with the base oil is to enhance its ability to act as a film layer between contact surfaces. Therefore there are different grades of lubricating oil with varying quality and unique purpose, and this determines the types of additives added [1].

According to Kadjas [4], lubricating oil is made up of base oil stock between 71.5-96.2 wt $\%$ and 3.8-28.5 wt $\%$ of additives blended together based on grade and specific duty. Various types of additives in typical lubricating oil composition is shown in Table 1[4].

Waste lubricating oil is distinctly a stable, almost homogeneous spread of undergirded base oil and additives contaminated with scrapings of metals from bearing surfaces, varnish, gums and other compounds from the degradation of the fresh engine oil [5]. About $50 \%$ of base oil globally are naphthenes containing largely cyclic compounds derived from naphthenic crude stocks. Chlorinated solvents may also be present in fairly large amount in SEO as a result of the degradation of additive packages. Sometimes, halogenated substances may results from addition of chlorine and bromine as lead scavengers in leaded gasoline. Polynuclear aromatic hydrocarbons (PAHs) contents made this spent lubricant carcinogenic [5]. Therefore, reclamation of the waste into virgin lubricating oil would be useful alternative to protect the environment. Recycling waste lubricating oil has embellished economic advantage due to high percentage of recoverable base oil than that from crude oil. 
Table 1. Composition of typical lubricating oil

\begin{tabular}{|l|l|}
\hline Ingredients & Wt \% \\
\hline SAE 30 or 40 base oil stock & $71.5-96.2$ \\
\hline Additives & \\
\hline Metallic detergent & $2.0-10.0$ \\
\hline Ash less dispersant & $1.0-9.0$ \\
\hline Antioxidant/anti wear & $0.1-2.0$ \\
\hline Friction modifier & $0.1-3.0$ \\
\hline Pour point depressant & $0.1-1.5$ \\
\hline Antifoam [ppm] & $2.0-15.0$ \\
\hline
\end{tabular}

Source: Kajdas, C, (2000) [4]

Used lubricating oil is one of the massive liquid wastes in the world that needs to be recovered for improved global economy.

Globally, several million tonnes of spent engine oil [SEO] are generated annually and disposed of discretely into the environment [6]. SEO had been handled basically three ways: (a) open disposal of the SEO on land, garbage heap and sewerage system, (b) reclamation of base-oil from SEO and (c) extracting the et al. heat content of SEO by combustion processes $[1,7]$.

In the course of usage, lubricating oils undergo degeneration and become contaminated by picking up contaminants from the system environment, including, residual lubricating oil, solids materials from frictional effects as well as corrosion products, soot, combustion products and dirt [8]. The contamination could include unsaturated hydrocarbons, aldehyde, phenolic compound, acidic compound, gums, additive, metals, varnish, and others [8]. Degradation involves changes in the hydrocarbons' molecular structure resulting from cracking, isomerization and polymerization reactions actuated by high temperatures in the crankcase of the running engine. Degradation results in formation of low hydrocarbon chain molecules and oxidation products such as polymerized or condensed molecules known as sludge and gum. In spite of impurities, a large amount of the base oil part in the SEO is usually preserved due to the high stability of the base oil [9]. SEO is an anthropogenic pollutant due to its toxicity, so dumping in the ground diminishes soil efficiency and affects negatively the edibility of the plants grown on it. Incineration of SEO releases PAHs to the environment while landfill disposal leads to seepage into underground water. Also, SEOs are used in all core industrial sectors such as railways, marine, manufacturing and transport for lubrication [10].

If managed properly, waste oil can be a very valuable resource. About $65-75 \%$ SEO content are base oil, which would constitute loss of valuable natural resource if burnt or dumped indiscriminately. [7]. Several methods reportedly utilized to recovery of spent lubricating oil in the literature include, but not limited to distillation [11], thermal dehydration [12], acid treating [13] solvent extraction, hydro treating [14] and combination of these methods [11 - 15]. Adsorptive removal of contaminants needs to be explored to adequately appropriate the hydrocarbons in the SEO. More so that Eleni et. al. [16] reported adsorption and membrane filtration to optimally remove contaminants from most industrial effluents. Several agricultural materials have been evaluated as adsorbent such as sawdust, sugarcane fiber, palm kernel shell, groundnut husk, maize cobs, sugar beet pulp, bamboo chips [17-22]). So, agricultural wastes materials having potentials as adsorbents could be extended to this purpose serving both environmental and economic values. The objective of this present study therefore, is to utilize waste agriculture materials as adsorbents for recovery of base oil hydrocarbons from spent engine oil. The expectation is conservation of environment, clean-up of wastes and energy generation.

Processing of fruits generates a lot of waste products including Chrysophyllum albidum seed shell. The activated carbon from Chrysophyllum albidum seed shell has been experimented for the adsorption of cadmium in wastewater among other toxic metals. It was also reported to have sequestering potentials for cadmium in waste water [23]. Extending the application of Chrysophyllum albidum seed shell to recovery of spent engine-oil will serve a dual purpose of economic recycling of waste petroleum product and environmental clean-up of agricultural wastes, more so that the 
inventory of spent engine oil for disposal will be reduced drastically. It will equally serve as low-cost industrial adsorbent.

This paper thus presents new frame work for spent oil re-usability, adapting African star apple seed shell which have hitherto been a waste agricultural matter, as adsorbent for that purpose.

\section{Materials and Methods}

Spent Lubricating Oil used for this study was collected from service station in Oshogbo, Osun State, South western Nigeria. It lies on coordinate $7^{\circ} 46^{\prime}$ North $4^{\circ} 34^{\prime}$ East. The sample was obtained from a heavy duty diesel truck after being used. The sample collected was transferred to a plastic container, stored away from light at room temperature. After a period of one (1) month, it was noticed that the suspended particles had settled under gravity. The sample was then decanted and the sludge containing the solid impurities, kept for further analysis. The decanted oil was centrifuged at 1000 rpm for 20 mins to remove the other insolubles in the spent oil.

Adsorbent Preparation and Characterization. The adsorbents used for this research were prepared from Walnut shell, Egg shell, African star apple fruit shell, and Rice husk. Wall nut and African star apple fruits as well as fresh eggs were collected from local farms, deshelled and kept for processing, while rice husk was collected from rice processing mill in Oshogbo, Osun state, south western Nigeria. The samples were grounded in a ball mill, sieved into different sizes using standard mesh. Apart from the egg shell, the samples were soaked in distilled water for 12 hour to remove water soluble matter. It was thereafter washed, boiled in distilled water for 1 hour, washed again, sundried and then oven dried at $105{ }^{\circ} \mathrm{C}$ to remove other volatiles. They were cooled and kept for analysis and use.

The adsorbent samples were characterized by determining the specific gravity at $30{ }^{\circ} \mathrm{C}$, Bulk Density $\left(\mathrm{g} / \mathrm{m}^{3}\right)$ and Porosity (\%), as well as X-ray fluorescence and the Textural analysis, using standard methods [24-25],

Specific Gravity (ASTM D 854-00). About known weight of sample $\left(\mathrm{W}_{O}\right)$ was measured into a clean dry pre-determined weight pycnometer $\left(\mathrm{W}_{\mathrm{P}}\right)$ and the weight of pycnometer and sample was determined (W $\mathrm{W}_{\mathrm{PS}}$ ). Distilled water was added to the sample to about 70 percent filled and allowed to soak for 5 minutes. Entrapped air was removed using vacuum pump connected to the pycnometer for 5 minutes. The pycnometer was then filled to mark with distilled water, cleansed and weighed $\left(\mathrm{W}_{\mathrm{B}}\right)$. The pcynometer was emptied, cleansed and then filled with distilled water only and weighed $\left(\mathrm{W}_{\mathrm{A}}\right)$.

The specific gravity was calculated as

Where,

$$
\text { Specific gravity, } S G=\frac{w_{0}}{W_{0}+\left(W_{A}-W_{B}\right)}
$$

$\mathrm{W}_{\mathrm{O}}=$ weight of dry sample, $\mathrm{g}=\mathrm{W}_{\mathrm{PS}}-\mathrm{W}_{\mathrm{P}}$

$\mathrm{W}_{\mathrm{A}}=$ weight of pycnometer filled with water

$\mathrm{W}_{\mathrm{B}}=$ weight of pycnometer filled with water and sample

Porosity and Bulk Density. A clean dry density bottle was weighed ( $\left.\mathrm{W}_{\mathrm{DB}}\right)$. The bottle was filled with water, corked and reweighed $\left(\mathrm{W}_{\mathrm{BA}}\right)$, small quantities of samples were gradually put into the bottles with little amount of water and weighed again $\left(\mathrm{W}_{\mathrm{BB}}\right)$. The bulk density and porosity were calculated using the following expressions.

$$
\begin{aligned}
& \text { Bulk density }=\frac{\text { mass of wet sample }=\mathrm{W}_{\mathrm{BB}}-\mathrm{W}_{\mathrm{DB}}}{\text { volume of the density bottle }=\mathrm{V}_{\mathrm{DB}}} \\
& \text { porosity, } \boldsymbol{\eta}=\frac{\mathrm{v}_{\mathrm{V}}}{\mathrm{V}_{\mathrm{DB}}}=\frac{\text { volume of void }}{\text { volume of the density bottle }}
\end{aligned}
$$

The volume of void, $\quad \mathbf{V}_{\mathbf{V}}=\mathbf{V}_{\mathbf{D B}}-\mathbf{V}_{\mathbf{S}}$ 
where, $V_{S}$ is the volume of sample and it is given by

$$
\left.\mathbf{V}_{\mathbf{S}}=\mathbf{M}_{\mathrm{s}} / \mathbf{S G} \boldsymbol{\rho} \mathrm{w}\right)
$$

Where $\mathrm{M}_{\mathrm{S}}=$ mass of solid, $\mathrm{SG}=$ specific gravity, and $\rho_{\mathrm{W}}=$ density of water.

Textural Properties. Texture Profile Analysis of the sample was performed using TA.XT plus Texture Analyzer (Stable Micro Systems Ltd., Godalming, Surrey, UK). The sample was compressed to $30 \%$ with a $100 \mathrm{~mm}$ diameter compression plate $(\mathrm{P} / 100)$ for texture profile analysis (TPA) at test speed of $5 \mathrm{~mm} / \mathrm{s}$, trigger force of $30 \mathrm{~g}$-auto for a period of $5 \mathrm{~s}$. The maximum force required to break the cookies was noted as hardness and gumminess and chewiness values were calculated [26].

XRF Analysis. X-Ray Fluorescence was used to analyze the elemental composition of the sample based on surface analysis. The sample was irradiated with X-rays in an energy dispersive Xray fluorescence spectrometer (Shimadzu EDXRF-702HS) operated at $40 \mathrm{kV}$ and $18 \mathrm{~mA}$. The intensity of element $\mathrm{K} \alpha$ counts per second $(\mathrm{cps} / \mu \mathrm{A})$ was obtained from the sample $\mathrm{X}$-ray spectrum using the Shimadzu EDX software package.

Fourier transformed infrared spectroscopy (FTIR). The type of functional groups of the sample was determined using SHIMADZU Happ-Genzel Fourier Transform Infrared Spectrophotometer. The samples were dried in an oven at $60{ }^{\circ} \mathrm{C}$ to remove the moisture. About 0.2 $\mathrm{mg}$ of sample and $2 \mathrm{mg}$ of potassium bromide were mixed and ground finely before the mixture was compressed to pellet. The infrared spectra of these samples were measured in the transmission of a wavelength $-1 \mathrm{n}$ umber range between 4000 and $400 \mathrm{~cm}$ [27] .

Clay Preparation. Clay sample used to pretreat the SEO was collected from a deposit in Oshogbo, washed with clean water and then with distilled water, sun dried then oven dried at temperature of $110^{\circ} \mathrm{C}$ for five (5) hours to eliminate the volatiles and organic matters in the clay. The sample was then allowed to cool gradually. The clay sample was then crushed and ground to particle size of $\leq 0.100 \mathrm{~mm}$ and stored in cool dry place for use.

Pre Treatment of SEO. Approximately $100 \mathrm{ml}$ of centrifuged spent lubricating oil sample was mixed with $20 \mathrm{~g}$ of the clay in a beaker and heated to $130{ }^{\circ} \mathrm{C}$, stirring continuously for one (1) hour with the electric stirrer maintained at the temperature of $130{ }^{\circ} \mathrm{C}$. The sample was then allowed to cool and then decanted. This process was carried out in fume controlled hood.

Adsorption Process. A $2.5 \mathrm{~cm}$ diameter graduated glass pipe was packed with the adsorbent to a height of $14 \mathrm{~cm}$ separately. The oil and each of the solvents were mixed in the oil:solvent ratio of $1: 1,1: 2,1: 3,1: 4,1: 5,1: 6,1: 7$ and $1: 10$ and the mixture shaken thoroughly to homogenize. It was observed that mixing was effective for oil to solvent ratio of 1:5 and above. This preliminary evaluation revealed hexane as the suitable solvent for the mobile phase due to its high miscibility, hence ability to carry the compounds of the SEO. Therefore, oil to solvent ratio 1:5 and 1:10 were considered for this research and hexane as the solvent eluant. The mixture was then pour into the packed column and allowed to run through the bed. The eluate from the column was collected and taken for GC-MS analysis.

Gas Chromatography Mass Spectrometry Analysis. The Gas Chromatography and Mass Spectrometry (GC-MS) analysis was done using a Varian 3800 gas chromatography equipped with an Agilent MS capillary column ( $30 \mathrm{~m}$ x $0.25 \mathrm{~mm}$ i.d.) connected to a Varian 4000 mass spectrometer operating in the EI mode $\left(70 \mathrm{ev} ; \mathrm{m} / \mathrm{z} 1-1000\right.$; source temperature $230^{\circ} \mathrm{C}$ and a quadruple temperature $150{ }^{\circ} \mathrm{C}$ ). The column temperature was initially maintained at $200{ }^{\circ} \mathrm{C}$ for $2 \mathrm{~min}$, increased to $300{ }^{\circ} \mathrm{C}$ at $4{ }^{\circ} \mathrm{C} / \mathrm{min}$, maintained for $20 \mathrm{~min}$ at $300{ }^{\circ} \mathrm{C}$. The carrier gas was nitrogen at a flow rate of $1.0 \mathrm{ml} / \mathrm{min}$. The inlet temperature was maintained at $300{ }^{\circ} \mathrm{C}$ with a split ratio of 50:1. A sample volume of $1 \mu 1$ in chloroform was set to scan in the range of $\mathrm{m} / \mathrm{z} 1-1000$ with electron impact (EI) mode of ionization. 


\section{Results and Discussion}

Preparation of Adsorbent. The African star apple fruit shell adsorbent has bulk density, specific gravity and porosity of $0.40 \mathrm{~g} / \mathrm{m}^{3}, 0.92$ and $12.5 \%$ respectively. The specific gravity value is close to the value of 0.89 reported by Olufunmilola and Oladapo [28] at the same temperature of $30{ }^{\circ} \mathrm{C}$.

In studying the effect of particle size on the adsorption process, the adsorbent was sieved with standard mesh to two fractions; the first fraction with particle size of $\leq 6 \mu \mathrm{m}$ were close to being powdery and the second fraction which have the particle size of $1.18 \mathrm{~mm}$ were granular in nature. The $1.18 \mathrm{~mm}$ fraction was used for the adsorption based on experience and literature [29]. The XRF analysis reported in Table 2 showed main chemical composition $\mathrm{Mg}, \mathrm{Na}$ and $\mathrm{K}$ constituting 95 percent component of the ASA adsorbent with $\mathrm{K}$ amounting to $74.14 \%$. It has low concentration of heavy metals with chromium having less than $2.4 \%$ occurrence and $\mathrm{Pb}, \mathrm{Cu}$ and $\mathrm{Cd}$ less than $0.022 \%$ Titanium has 0.108 percent occurrence.

Table 2. XRF analysis of ASA sample

\begin{tabular}{|l|l|l|l|l|}
\hline $\mathbf{S} / \mathbf{N}$ & Parameters & Symbol & Composition (mg/g) & $\begin{array}{l}\text { Occurrence } \\
\text { (wt \%) }\end{array}$ \\
\hline 1 & Phosphorus & $\mathrm{P}$ & 2.20 & 0.579 \\
\hline 2 & Zinc & $\mathrm{Zn}$ & 0.23 & 0.061 \\
\hline 3 & Iron & $\mathrm{Fe}$ & 3.82 & 1.006 \\
\hline 4 & Calcium & $\mathrm{Ca}$ & 0.86 & 0.226 \\
\hline 5 & Magnesium & $\mathrm{Mg}$ & 39.42 & 10.377 \\
\hline 6 & Sodium & $\mathrm{Na}$ & 40.00 & 10.529 \\
\hline 7 & Potassium & $\mathrm{K}$ & 281.64 & 74.137 \\
\hline 8 & Chloride & $\mathrm{Cl}$ & 0.57 & 0.150 \\
\hline 9 & Aluminum & $\mathrm{Al}$ & 0.22 & 0.058 \\
\hline 10 & Lead & $\mathrm{Pb}$ & 0.08 & 0.021 \\
\hline 11 & Chromium & $\mathrm{Cr}$ & 8.94 & 2.353 \\
\hline 12 & Copper & $\mathrm{Cu}$ & 1.02 & 0.268 \\
\hline 13 & Cadmium & $\mathrm{Cd}$ & 0.01 & 0.003 \\
\hline 14 & Titanium & $\mathrm{Ti}$ & 0.41 & 0.108 \\
\hline 15 & Loss of ignition & $\mathrm{LOI}$ & 0.47 & 0.124 \\
\hline & Total & $\mathbf{3 7 9 . 8 9}$ & $\mathbf{1 0 0 . 0 0 0}$ \\
\hline
\end{tabular}

The result of textural analysis of the sample showed that the adsorbent has hardness of $87.14 \mathrm{~N}$, gumminess of $75.56 \mathrm{~N}$ and Chewiness of $75.03 \mathrm{~N}$. These parameters indicates moderate cohesiveness and compactness of the adsorbent.

FTIR analysis. The wave number range of FT-IR spectrum (Fig. 1) is from $4000 \mathrm{~cm}^{-1}$ to $400 \mathrm{~cm}^{-1}$. The peaks located at 1758.06 and $2710.33 \mathrm{~cm}^{-1}$ are the characteristic of carbonyl group stretching from aldehydes and ketones [30] and C-H stretching of aldehyde of $2841.53 \mathrm{~cm}^{-1}$ of aldehyde [31]. The ethereal C-O-C stretching is observed at $1410 \mathrm{~cm}^{-1}$. The absorption at $936.25 \mathrm{~cm}^{-1}$ is due to $-\mathrm{OH}$ group bending vibration of carboxylic acid. The peaks in the range $1242.65-1117.08 \mathrm{~cm}^{-1}$ are significant of amines $-\mathrm{C}-\mathrm{N}$ stretching. This observation reflected the report of Ajayi eta al [32] that major components of African star apple seed shell comprised stigmasterole, myricetin-3-rhamnoside, beta amyrin acetate, eleagnine and gentisic acid. The spectrum is significantly similar to that observed for the Chrysophyllum albidum seed oil [33]. It can be concluded that hydroxyl, carboxyl, carbonyl and hydrocarbyl groups are the main components of ASA adsorbent with presence of amine and halides. 


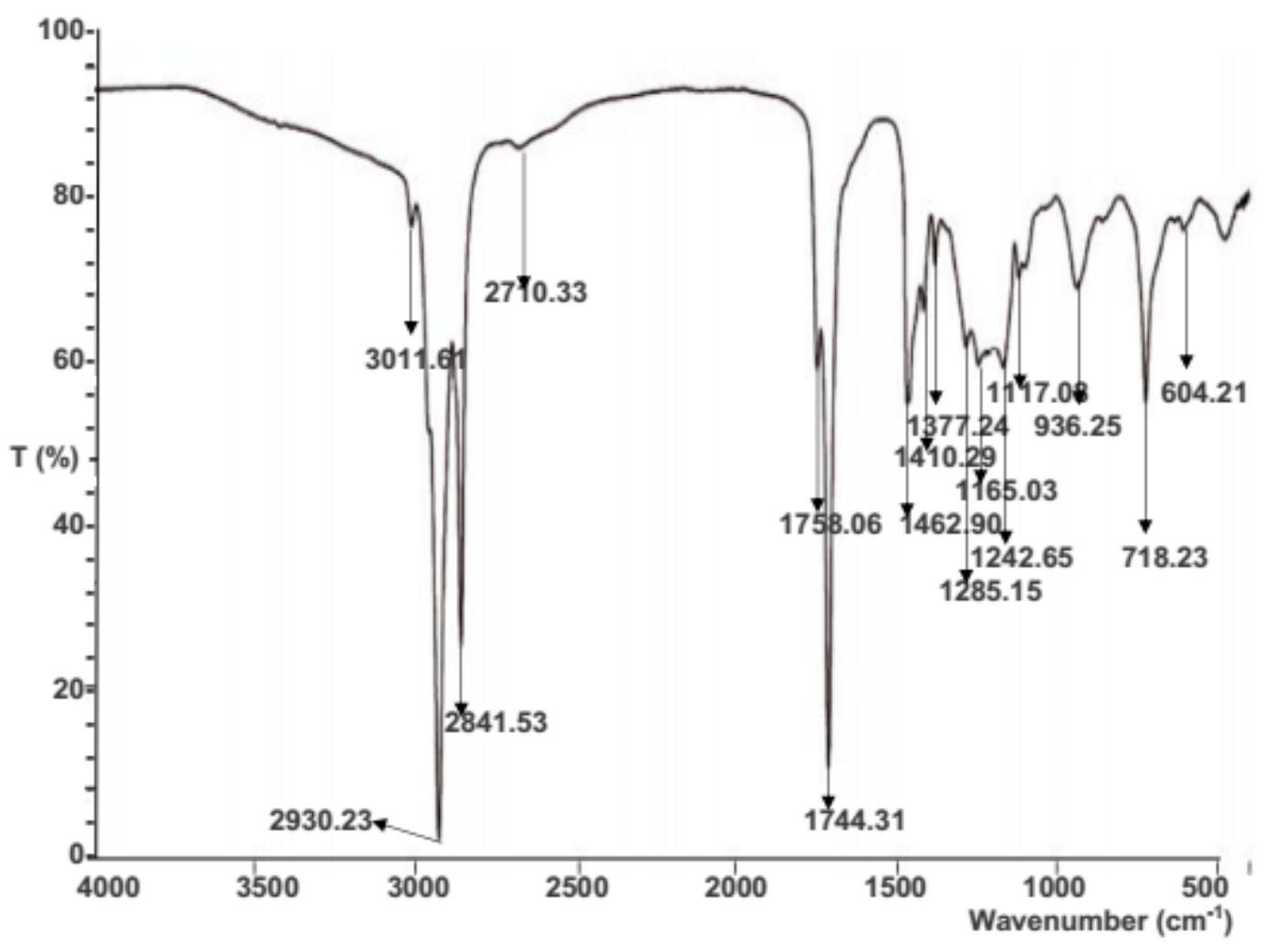

Fig 1. FT-IR Spectrum of ASA Adsorbent

GC-MS Analysis Result. The experimental results of the Gas Chromatography-Mass Spectrometry (GC-MS) analysis for all the recovered samples from the adsorptive chromatographic separation of spent lubricating oil are presented for the fresh lubricating oil, used lubricating oil and that of recovered oil in Tables 3, 4 and 5, respectively. Several compounds were identified in the fresh lubricating oil including phytane $\left(\mathrm{C}_{20} \mathrm{H}_{42}\right)$ having the highest occurrence of 12.00 weight $\%$. The least occurring compound identified is 2, 4-bis-(t-butyl)-methoxy benzene $\left(\mathrm{C}_{16} \mathrm{H}_{26} \mathrm{O}_{2}\right)$ having 0.04 weight \% occurrence. About 60 weight percent of the compounds are unsaturated which are either cyclic, benzyl or enyl derivatives. Its GC-MS chromatogram is shown in Fig 2. The longest carbon chain compound identified in the fresh lubricating oil sample is $\mathrm{N}$-dotriacontane $\left(\mathrm{C}_{32} \mathrm{H}_{66}\right)$ which is a saturated hydrocarbon and occur at 0.54 weight percent. This corroborates the report of Taiwo and Bello [11] that the lubricating oil usually contains hydrocarbons with $\leq \mathrm{C} 32$ carbon length. The compounds identified in untreated SEO using GC-MS analysis (Fig. 3), showed dibenzo-thiophene $\left(\mathrm{C}_{12} \mathrm{H}_{8} \mathrm{~S}\right)$ having the highest occurrence of 9.46 weight $\%$, and perylene $\left(\mathrm{C}_{20} \mathrm{H}_{12}\right)$ with 0.02 weight $\%$, being the lowest occurrence compound in the sample. Comparing Tables 3 and 4, it could be observed that almost all compounds present in the fresh lubricating oil are present in spent lubricating oil. This revealed lubricating oil as a petroleum product which is not fully consumed during use, corroborating the report of [15]. However, acetic acid $\left(\mathrm{C}_{2} \mathrm{H}_{4} \mathrm{O}_{2}\right)$, acetaldehyde $\left(\mathrm{C}_{2} \mathrm{H}_{4} \mathrm{O}\right), 1$, 2- benzene dicarboxylic acid $\left(\mathrm{C}_{8} \mathrm{H}_{6} \mathrm{O}_{4}\right)$ and dibutyl ester $\left(\mathrm{C}_{12} \mathrm{H}_{22} \mathrm{O}_{4}\right)$ are not present in the fresh oil. The presence of these compounds could have resulted from contamination of the lubricating oil due to usage in the engine. 


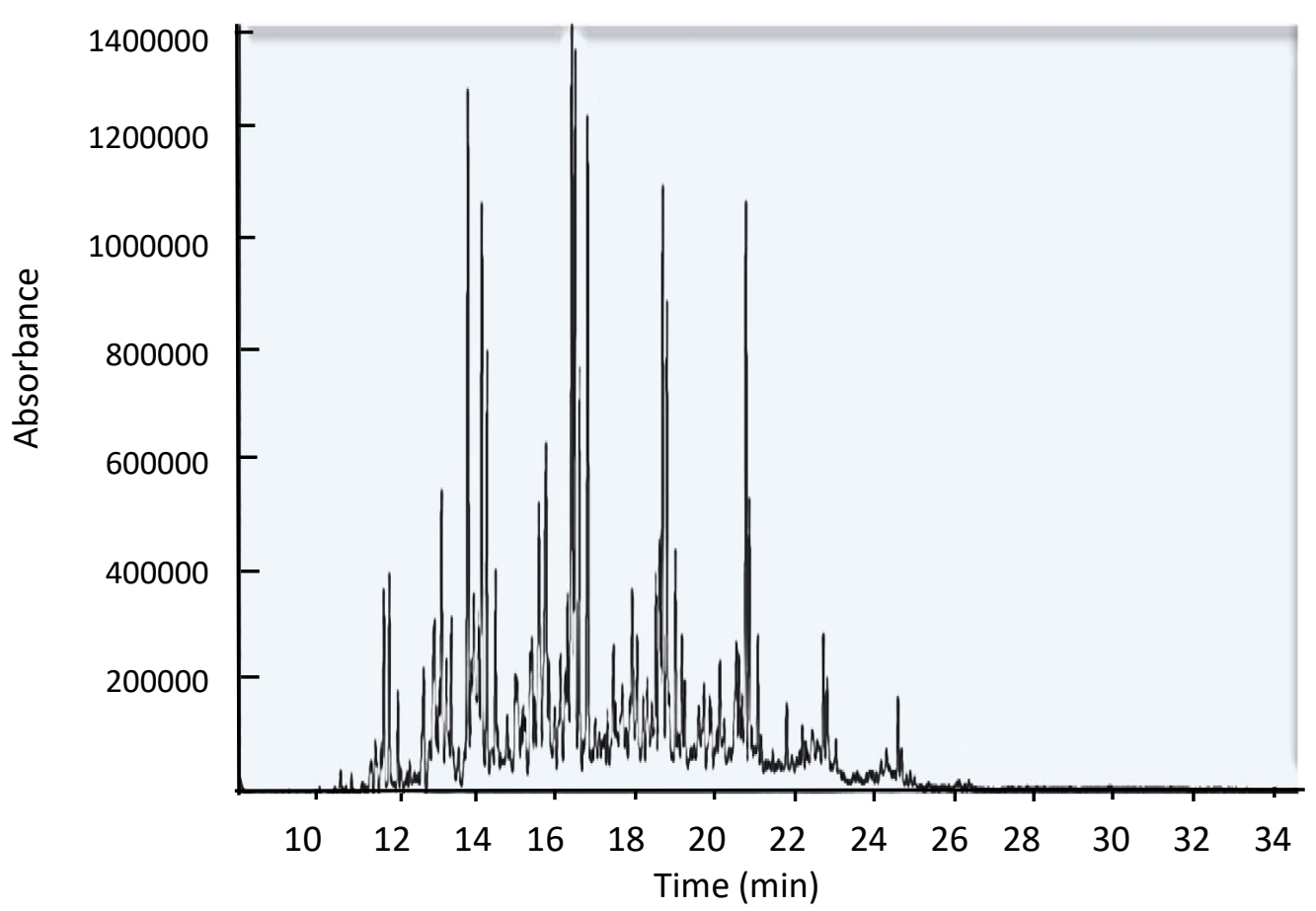

Fig 2. GC spectrum of fresh lube oil

Similarly, some compounds, such as, oleanane $\left(\mathrm{C}_{30} \mathrm{H}_{52}\right)$, N-dortriacontane $\left(\mathrm{C}_{32} \mathrm{H}_{66}\right)$, tetradecane trimethyl $\left(\mathrm{C}_{17} \mathrm{H}_{32}\right)$, hopane $\left(\mathrm{C}_{30} \mathrm{H}_{52}\right)$ occurring in VEO were not found in the SEO implying possible conversion or breakdown of these hydrocarbons, which were in the range $\mathrm{C} 17$ to C30. Oleanane, gammacerane and hopanes are C30 isomers of pentacyclic triterpenoid. Thermal degradation of these terpenoids could lead to dehydrogenation producing aromatic systems, or epoxidation, or oxidative cleavage of double bond resulting to aldehyde or ketone generation, or allylic oxidation and rearrangement to form alcohols, ketones and aldehyde [34, 35]. A schematic representation of these possible conversion of terpenoids is given in Fig. 4.

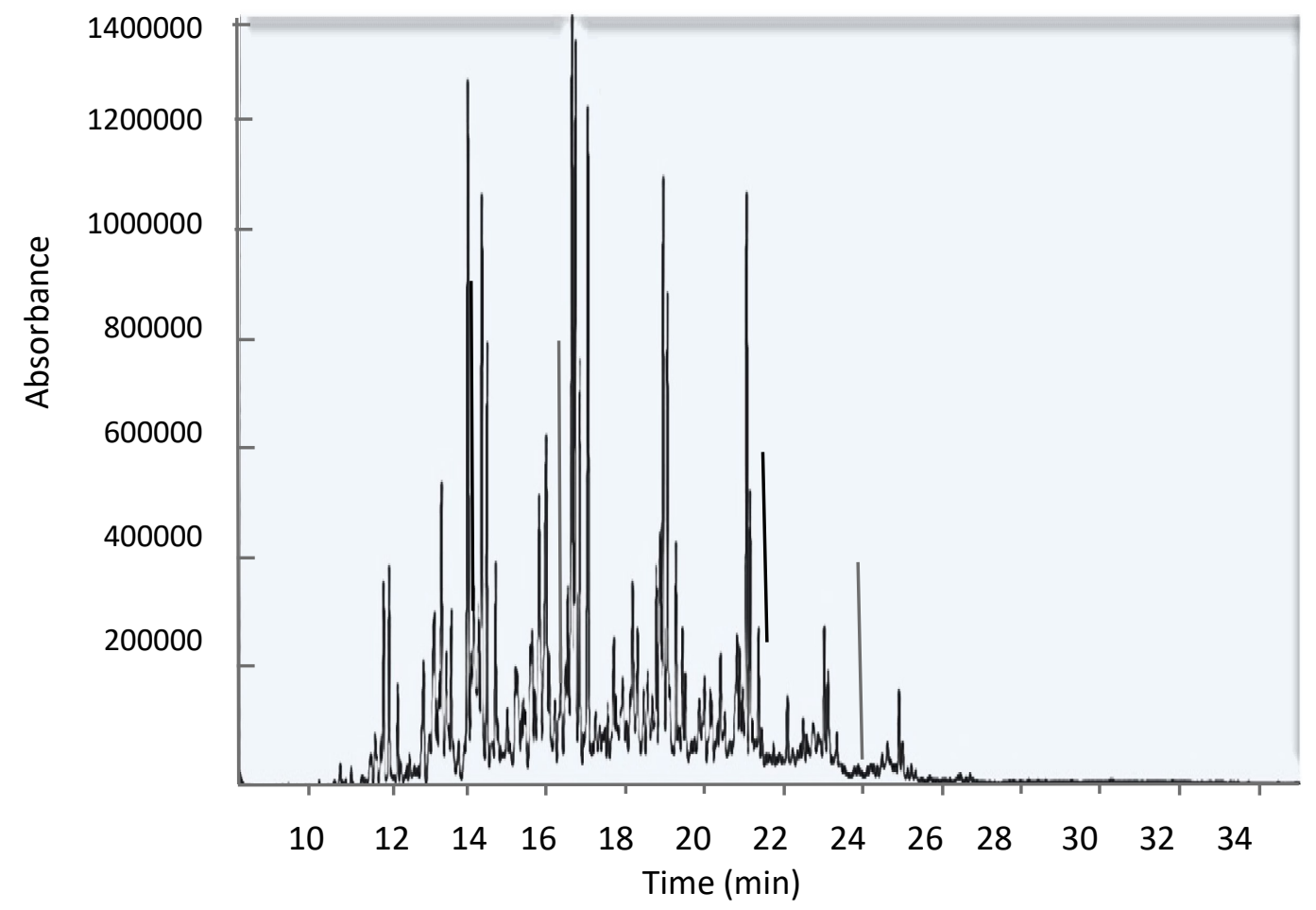

Fig 3. GC spectrum of untreated spent engine oil 
Acetic acid occurrence in the spent lubricating oil might have resulted from oxidation of light naphtha components which could have been obtained from catalytic cracking of Biphenyl or fluorene and even naphthalene present in the fresh lubricating oil, oxidized by oxygen or even air to give peroxides, decomposing further to produce acetic acid [36, 37].

\section{$\mathrm{C}_{10} \mathrm{H}_{8}+2_{2} \mathrm{O}_{2} \mathrm{C}_{6} \mathrm{H}_{4}(\mathrm{CHO})_{2}+\mathrm{CH}_{3} \mathrm{CO}_{2} \mathrm{H}$}

The above oxidation requires metal-based catalyst which could have been obtained from metal scrapings resulting from rubbing surfaces due to friction. The presence of these compounds are probably responsible for the contamination of the spent lubricating oil.

Table 3. Identified Compounds from GC-MS Analysis of FEO Sample

\begin{tabular}{|c|c|c|c|c|}
\hline $\mathbf{S} / \mathbf{N}$ & Compound & \begin{tabular}{|l|} 
Molecular \\
Formula
\end{tabular} & $\begin{array}{l}\text { Molecular } \\
\text { Mass }\end{array}$ & wt $\%$ \\
\hline 1 & Naphthalene & $\mathrm{C}_{10} \mathrm{H}_{8}$ & 128.17 & 1.45 \\
\hline 2 & Floroethene & $\mathrm{C}_{2} \mathrm{H}_{3} \mathrm{~F}$ & 62.50 & 0.08 \\
\hline 3 & Propan-2-ol & $\mathrm{C}_{3} \mathrm{H}_{8} \mathrm{O}$ & 60.10 & 1.02 \\
\hline 4 & Butadiene & $\mathrm{C}_{4} \mathrm{H}_{6}$ & 54.06 & 0.19 \\
\hline 5 & Biphenyl & $\mathrm{C}_{12} \mathrm{H}_{10}$ & 154.21 & 1.83 \\
\hline 6 & Acenaphthylene & $\mathrm{C}_{12} \mathrm{H}_{8}$ & 152.20 & 3.80 \\
\hline 7 & Pyrene & $\mathrm{C}_{16} \mathrm{H}_{10}$ & 202.25 & 9.63 \\
\hline 8 & Perylene & $\mathrm{C}_{20} \mathrm{H}_{12}$ & 252.32 & 0.32 \\
\hline 9 & Anthracene & $\mathrm{C}_{14} \mathrm{H}_{10}$ & 178.23 & 6.08 \\
\hline 10 & Ethylene glycol & $\mathrm{C}_{2} \mathrm{H}_{6} \mathrm{O}_{2}$ & 62.07 & 4.81 \\
\hline 11 & Tridecanol & $\mathrm{C}_{13} \mathrm{H}_{28} \mathrm{O}$. & 200.40 & 0.35 \\
\hline 12 & Pristane & $\mathrm{C}_{19} \mathrm{H}_{40}$ & 268.51 & 0.72 \\
\hline 13 & Phytane & $\mathrm{C}_{20} \mathrm{H}_{42}$ & 282.56 & 11.70 \\
\hline 14 & Steranes & $\mathrm{C}_{29} \mathrm{H}_{52}$ & 400.74 & 2.69 \\
\hline 15 & Dibenzo-thiophene & $\mathrm{C}_{12} \mathrm{H}_{8} \mathrm{~S}$ & 184.26 & 6.44 \\
\hline 16 & Benzo-naphtho-thiophene. & $\mathrm{C}_{16} \mathrm{H}_{10} \mathrm{~S}$ & 234.32 & 3.83 \\
\hline 17 & Phenanthrene & $\mathrm{C}_{14} \mathrm{H}_{28} \mathrm{O}_{2}$ & 228.12 & 5.32 \\
\hline 18 & Oleanane & $\mathrm{C}_{30} \mathrm{H}_{52}$ & 412.75 & 1.75 \\
\hline 19 & Gammacerane, & $\mathrm{C}_{30} \mathrm{H}_{52}$ & 412.75 & 1.50 \\
\hline 20 & Decamethylcyclopentasiloxane & $\mathrm{C}_{10} \mathrm{H}_{30} \mathrm{O}_{5} \mathrm{Si}_{5}$ & 370.77 & 2.90 \\
\hline 21 & N-Dotriacontane & $\mathrm{C}_{32} \mathrm{H}_{66}$ & 450.88 & 0.54 \\
\hline 22 & Fluorene & $\mathrm{C}_{13} \mathrm{H}_{10}$ & 166.32 & 5.06 \\
\hline 23 & Chrysene & $\mathrm{C}_{18} \mathrm{H}_{12}$ & 228.29 & 3.77 \\
\hline 24 & Tetradecane 2,6,10 trimethyl & $\mathrm{C}_{17} \mathrm{H}_{32}$ & 240.72 & 8.47 \\
\hline 25 & Benzo[k]fluoranthrene & $\mathrm{C}_{20} \mathrm{H}_{12}$ & 252.32 & 1.11 \\
\hline 26 & 2-Ethyl-1-hexanol & $\mathrm{C}_{8} \mathrm{H}_{18} \mathrm{O}$ & 130.23 & 0.54 \\
\hline 27 & Decanoic acid methyl ester & $\mathrm{C}_{11} \mathrm{H}_{22} \mathrm{O}_{2}$ & 186.30 & 0.09 \\
\hline 28 & 2,4-bis-(t-butyl)-methoxy benzene & $\mathrm{C}_{16} \mathrm{H}_{26} \mathrm{O}_{2}$ & 250.38 & 0.04 \\
\hline 29 & Cyclopenta (cd) pyrene & $\mathrm{C}_{18} \mathrm{H}_{10}$ & 226.28 & 0.90 \\
\hline 30 & Hopanes & $\mathrm{C}_{30} \mathrm{H}_{52}$ & 412.75 & 0.18 \\
\hline 31 & Indeno(1,2,3-cd)pyrene & $\mathrm{C}_{22} \mathrm{H}_{12}$ & 276.34 & 4.81 \\
\hline 32 & Dibenzo(ah)anthracene & $\mathrm{C}_{22} \mathrm{H}_{14}$ & 278.35 & 3.34 \\
\hline 33 & Benzo(ghi)perylene & $\mathrm{C}_{22} \mathrm{H}_{12}$ & 276.34 & 1.16 \\
\hline 34 & 3,5-bis(t-butyl)-Phenol & $\mathrm{C}_{14} \mathrm{H}_{22} \mathrm{O}$ & 206.32 & 0.62 \\
\hline 35 & Benzo(a)pyrene & $\mathrm{C}_{20} \mathrm{H}_{12}$ & 252.31 & 3.01 \\
\hline
\end{tabular}


Table 4. GC-MS Analysis for Untreated Spent Lubricating Oil

\begin{tabular}{|c|c|c|c|c|}
\hline $\mathbf{S} / \mathbf{N}$ & Compound & $\begin{array}{l}\text { Molecular } \\
\text { Formula }\end{array}$ & $\begin{array}{l}\text { Molecular } \\
\text { Mass }\end{array}$ & wt \% \\
\hline 1 & Naphthalene & $\mathrm{C}_{10} \mathrm{H}_{8}$ & 128.17 & 2.75 \\
\hline 2 & Acetic acid & $\mathrm{C}_{2} \mathrm{H}_{4} \mathrm{O}_{2}$ & 60.05 & 3.84 \\
\hline 3 & Propan-2-ol & $\mathrm{C}_{3} \mathrm{H}_{8} \mathrm{O}$ & 60.10 & 0.02 \\
\hline 5 & Butadiene & $\mathrm{C}_{4} \mathrm{H}_{6}$ & 54.06 & 0.16 \\
\hline 6 & 2,6-bis- (t-butyl)Phenol & $\mathrm{C}_{14} \mathrm{H}_{22} \mathrm{O}$ & 206.33 & 1.38 \\
\hline 7 & Acetaldehyde & $\mathrm{C}_{2} \mathrm{H}_{4} \mathrm{O}$ & 40.06 & 2.96 \\
\hline 8 & Acenaphthylene & $\mathrm{C}_{12} \mathrm{H}_{8}$ & 152.2 & 1.90 \\
\hline 9 & Pyrene & $\mathrm{C}_{16} \mathrm{H}_{10}$ & 202.25 & 4.07 \\
\hline 10 & Perylene & $\mathrm{C}_{20} \mathrm{H}_{12}$ & 252.32 & 0.02 \\
\hline 11 & Anthracene & $\mathrm{C}_{14} \mathrm{H}_{10}$ & 178.23 & 3.45 \\
\hline 12 & Ethylene glycol & $\mathrm{C}_{2} \mathrm{H}_{6} \mathrm{O}_{2}$ & 62.07 & 2.02 \\
\hline 13 & Tridecanol & $\mathrm{C}_{13} \mathrm{H}_{28} \mathrm{O}$. & 200.40 & 0.12 \\
\hline 14 & Pristane & $\mathrm{C}_{19} \mathrm{H}_{40}$ & 268.51 & 0.13 \\
\hline 15 & Phytane & $\mathrm{C}_{20} \mathrm{H}_{42}$ & 282.56 & 5.21 \\
\hline 16 & Steranes & $\mathrm{C}_{29} \mathrm{H}_{52}$ & 400.74 & 5.26 \\
\hline 17 & 1,2-Benzene dicarboxylic acid & $\mathrm{C}_{8} \mathrm{H}_{6} \mathrm{O}_{4}$ & 400.74 & 3.43 \\
\hline 18 & Dibenzo-thiophene & $\mathrm{C}_{12} \mathrm{H}_{8} \mathrm{~S}$ & 184.26 & 9.46 \\
\hline 19 & Benzo-naphtho-thiophene. & $\mathrm{C}_{16} \mathrm{H}_{10} \mathrm{~S}$ & 234.32 & 4.29 \\
\hline 20 & Phenanthrene & $\mathrm{C}_{14} \mathrm{H}_{28} \mathrm{O}_{2}$ & 228.12 & 1.48 \\
\hline 21 & 1,1-Diphenyl hydrazine & $\mathrm{C}_{12} \mathrm{H}_{12} \mathrm{~N}_{2}$ & 184.24 & 1.19 \\
\hline 22 & Decamethylcyclopentasiloxane & $\mathrm{C}_{10} \mathrm{H}_{30} \mathrm{O}_{5} \mathrm{Si}_{5}$ & 370.77 & 5.50 \\
\hline 23 & Fluorene & $\mathrm{C}_{13} \mathrm{H}_{10}$ & 166.32 & 5.85 \\
\hline 24 & dibutyl ester & $\mathrm{C}_{12} \mathrm{H}_{22} \mathrm{O}_{4}$ & 230.30 & 5.64 \\
\hline 25 & Chrysene & $\mathrm{C}_{18} \mathrm{H}_{12}$ & 228.29 & 3.11 \\
\hline 26 & Benzo[k]fluoranthrene & $\mathrm{C}_{20} \mathrm{H}_{12}$ & 252.32 & 4.61 \\
\hline 27 & 2-Ethyl-1-hexanol & $\mathrm{C}_{8} \mathrm{H}_{18} \mathrm{O}$ & 130.23 & 0.38 \\
\hline 28 & Decanoic acid methyl ester & $\mathrm{C}_{11} \mathrm{H}_{22} \mathrm{O}_{2}$ & 186.30 & 0.44 \\
\hline 29 & 2,4-bis-(t-butyl)-methoxy Benzene & $\mathrm{C}_{16} \mathrm{H}_{26} \mathrm{O}_{2}$ & 250.38 & 0.27 \\
\hline 30 & Cyclopenta (cd) pyrene & $\mathrm{C}_{18} \mathrm{H}_{10}$ & 226.28 & 2.13 \\
\hline 31 & Indeno(1,2,3-cd)pyrene & $\mathrm{C}_{22} \mathrm{H}_{12}$ & 276.34 & 6.51 \\
\hline 32 & Dibenzo(ah)anthracene & $\mathrm{C}_{22} \mathrm{H}_{14}$ & 278.35 & 4.87 \\
\hline 33 & Benzo(ghi)perylene & $\mathrm{C}_{22} \mathrm{H}_{12}$ & 276.34 & 3.53 \\
\hline 34 & 3,5-bis(t-butyl)-Phenol & $\mathrm{C}_{14} \mathrm{H}_{22} \mathrm{O}$ & 206.32 & 0.25 \\
\hline 35 & Benzo(a)pyrene & $\mathrm{C}_{20} \mathrm{H}_{12}$ & 252.31 & 3.70 \\
\hline
\end{tabular}




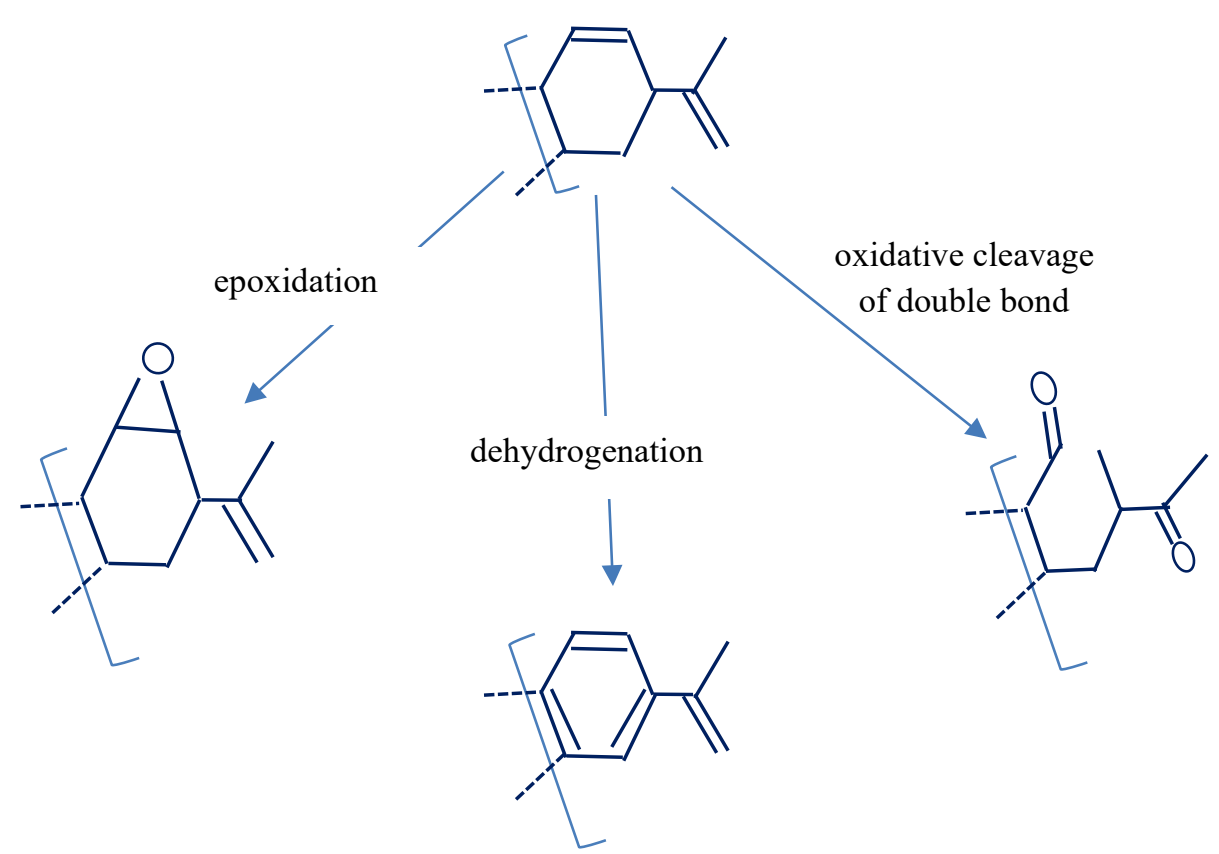

Fig. 4. Schematic representation of terpenoids conversion

The pretreated SEO using the clay sample has a clearer colour relative to the untreated sample. Its kinematic viscosity of $278.4 \mathrm{~mm}^{2} \mathrm{~s}^{-1}$ was less than the untreated SEO having viscosity of $292.6 \mathrm{~mm}^{2} \mathrm{~s}^{-1}$ reported by Taiwo and Bello [11] indicating removal of some impurities. This was also observed to result from removal of heavy aromatics alongside the sludge while recovering spent engine oil using calcined clay [38]. The identified hydrocarbons are reported in Table 4 and has very much less compounds than that obtained for untreated SEO. For instance, propan-2-ol, fluorene, butadiene, 2,6-bis-(t-butyl) phenol, pristane, phytane, stearates, benzo-napththo-thiophene, 1,1-diphenyl hydrazine, decanoic acid methyl ester, 3,5-bis(t-butyl)-phenol had been eliminated by the clay by either conversion or and adsorption on the clay pore spaces. This finding presents clay as a low-cost industrial adsorbent.

The clay treated SEO was then ran through column packed with ASA adsorbent and GC spectrum is reported in Fig 5. The components presented by the MS fragmentation is given in Table 6 . It has about 70 weight percent aromatics including dibenzo-thiophene with relative occurrence of 18.32 weight $\%$ as the highest occurring compound, followed by cyclopenta(cd)pyrene with 10.28 weight $\%$ with perylene having the least occurrence of 0.02 weight $\%$ respectively. Relative to the clay treated sample, components like chrysene, benzo(a)pyrene, 2-bromonaphthalene, dibenzo(ah)anthracene and flouranthene were trapped in the adsorbent. It could be observed that most of the trapped compounds have carbon atoms $\geq 20$ in the molecules. In the preliminary evaluation of the eluting solvents, it has been discovered that the ASA adsorbent was unable to separate the SEO thus the utilization of clay for pretreatment of the spent oil. A combination of clay/ASA therefore formed a good adsorbent for recovering hydrocarbons which are majorly aromatics, from the SEO. This process offers an improved re-refining option to the distillation process which is energy intensive. The aromatics are useful feedstock to petrochemical industries.

The possible reactions during lubricant usage in the crankcase were thermal dehydrogenation, ring opening, epoxidation, cracking, and condensation of aromatics such as, phenyloctane, biphenyl, fluorene, 9,10-dihydrophenanthrene, naphthalene, phenanthrene, pyrene, and benzo(a)anthracene which are base oil components or additives in the lubricant formulation [39]. 
Table 5. GC-MS Analysis for Clay treated Spent Lubricating Oil

\begin{tabular}{|l|l|l|l|l|}
\hline $\mathbf{S} / \mathbf{N}$ & Compound & $\begin{array}{l}\text { Molecular } \\
\text { Formula }\end{array}$ & $\begin{array}{l}\text { Molecular } \\
\text { Mass }\end{array}$ & wt \% \\
\hline 1 & Naphthalene & $\mathrm{C}_{10} \mathrm{H}_{8}$ & 128.17 & 2.85 \\
\hline 2 & Acetic acid & $\mathrm{CH}_{3} \mathrm{COOH}$ & 60.05 & 5.12 \\
\hline 3 & Acetaldehyde & $\mathrm{C}_{2} \mathrm{H}_{4} \mathrm{O}$ & 40.06 & 3.96 \\
\hline 4 & Acenaphthylene & $\mathrm{C}_{12} \mathrm{H}_{8}$ & 152.20 & 1.55 \\
\hline 5 & Pyrene & $\mathrm{C}_{16} \mathrm{H}_{10}$ & 202.25 & 4.55 \\
\hline 6 & Perylene & $\mathrm{C}_{20} \mathrm{H}_{12}$ & 252.32 & 0.02 \\
\hline 7 & Anthracene & $\mathrm{C}_{14} \mathrm{H}_{10}$ & 178.23 & 3.17 \\
\hline 8 & Ethylene glycol & $\mathrm{C}_{2} \mathrm{H}_{6} \mathrm{O}_{2}$ & 62.07 & 1.62 \\
\hline 9 & Tridecanol & $\mathrm{C}_{13} \mathrm{H}_{28} \mathrm{O}$ & 200.40 & 0.07 \\
\hline 10 & $1,2-$-Benzene dicarboxylic acid & $\mathrm{C}_{8} \mathrm{H}_{6} \mathrm{O}_{4}$ & 400.74 & 4.59 \\
\hline 11 & Dibenzo-thiophene & $\mathrm{C}_{12} \mathrm{H}_{8} \mathrm{~S}$ & 184.26 & 11.80 \\
\hline 12 & Phenanthrene & $\mathrm{C}_{14} \mathrm{H}_{28} \mathrm{O}_{2}$ & 228.12 & 0.93 \\
\hline 13 & Decamethylcyclopentasiloxane & $\mathrm{C}_{10} \mathrm{H}_{30} \mathrm{O}_{5} \mathrm{Si}{ }_{5}$ & 370.77 & 7.19 \\
\hline 14 & dibutyl ester & $\mathrm{C}_{12} \mathrm{H}_{22} \mathrm{O}_{4}$ & 230.30 & 7.53 \\
\hline 15 & Chrysene & $\mathrm{C}_{18} \mathrm{H}_{12}$ & 228.29 & 0.99 \\
\hline 16 & benzo(k)fluoranthene & $\mathrm{C}_{20} \mathrm{H}_{12}$ & 252.30 & 3.45 \\
\hline 17 & 2 -Ethyl-1-hexanol & $\mathrm{C}_{8} \mathrm{H}_{18} \mathrm{O}$ & 130.23 & 0.70 \\
\hline 18 & 2,4-bis-(t-butyl)-methoxy Benzene & $\mathrm{C}_{16} \mathrm{H}_{26} \mathrm{O}_{2}$ & 250.38 & 1.17 \\
\hline 19 & Cyclopenta (cd) pyrene & $\mathrm{C}_{18} \mathrm{H}_{10}$ & 226.28 & 6.52 \\
\hline 20 & Indeno(1,2,3-cd)pyrene & $\mathrm{C}_{22} \mathrm{H}_{12}$ & 276.34 & 7.61 \\
\hline 21 & Dibenzo(ah)anthracene & $\mathrm{C}_{22} \mathrm{H}_{14}$ & 278.35 & 6.17 \\
\hline 22 & Benzo(ghi)perylene & $\mathrm{C}_{22} \mathrm{H}_{12}$ & 276.34 & 5.23 \\
\hline 23 & Benzo(a)pyrene & $\mathrm{C}_{20} \mathrm{H}_{12}$ & 252.31 & 1.07 \\
\hline 24 & 2-bromonaphthalene & $\mathrm{C}_{10} \mathrm{H}_{7} \mathrm{Br}$ & 207.07 & 2.41 \\
\hline 25 & benzo(a)anthracene & $\mathrm{C}_{18} \mathrm{H}_{12}$ & 228.30 & 3.47 \\
\hline 26 & Fluoranthene & $\mathrm{C}_{16} \mathrm{H}_{10}$ & 202.26 & 2.85 \\
\hline 27 & Fluorene & $\mathrm{C}_{13} \mathrm{H}_{10}$ & 166.323 & 3.48 \\
\hline & & & & \\
\hline
\end{tabular}

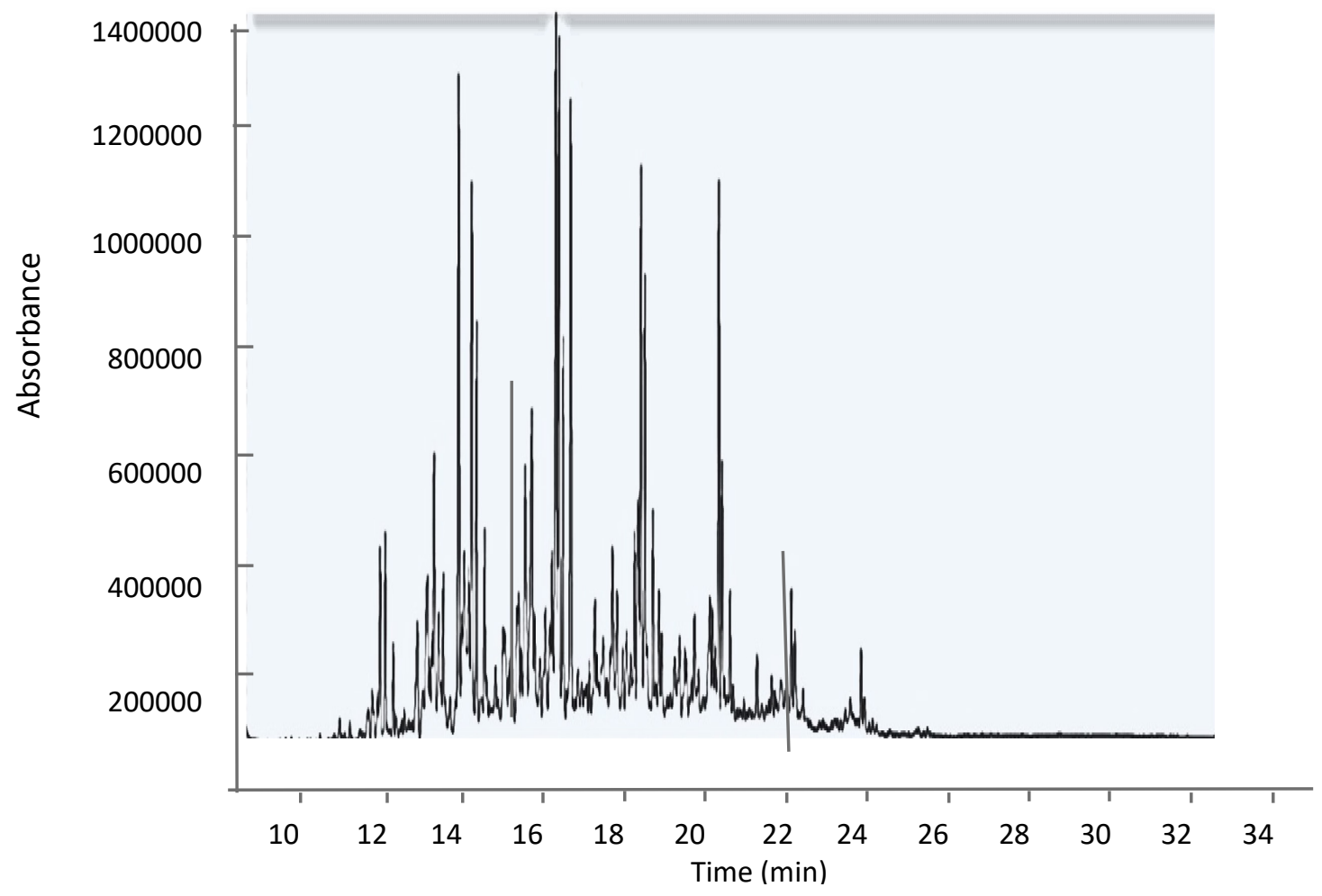

Fig. 5. GC-MS Spectrum of eluate from ASA Adsorbent 
Table 6. GC-MS Analysis for Eluate from African Star Apple Fruit Shell Adsorbent

\begin{tabular}{|l|l|l|l|l|}
\hline $\mathbf{S} / \mathbf{N}$ & Compound & $\begin{array}{l}\text { Molecular } \\
\text { Formula }\end{array}$ & $\begin{array}{l}\text { Molecular } \\
\text { Mass }\end{array}$ & wt \% \\
\hline 1 & Naphthalene & $\mathrm{C}_{10} \mathrm{H}_{8}$ & 128.17 & 4.43 \\
\hline 2 & Acetic acid & $\mathrm{CH}_{3} \mathrm{COOH}$ & 60.05 & 7.98 \\
\hline 3 & Acetaldehyde & $\mathrm{C}_{2} \mathrm{H}_{4} \mathrm{O}$ & 40.06 & 2.46 \\
\hline 4 & Acenaphthylene & $\mathrm{C}_{12} \mathrm{H}_{8}$ & 152.20 & 3.98 \\
\hline 5 & Pyrene & $\mathrm{C}_{16} \mathrm{H}_{10}$ & 202.25 & 7.10 \\
\hline 6 & Perylene & $\mathrm{C}_{20} \mathrm{H}_{12}$ & 252.32 & 0.02 \\
\hline 7 & Anthracene & $\mathrm{C}_{14} \mathrm{H}_{10}$ & 178.23 & 4.93 \\
\hline 8 & Ethylene glycol & $\mathrm{C}_{2} \mathrm{H}_{6} \mathrm{O}_{2}$ & 62.07 & 2.52 \\
\hline 9 & Tridecanol & $\mathrm{C}_{13} \mathrm{H}_{28} \mathrm{O}$. & 200.40 & 0.08 \\
\hline 10 & 1,2-Benzene dicarboxylic acid & $\mathrm{C}_{8} \mathrm{H}_{6} \mathrm{O}_{4}$ & 400.74 & 7.13 \\
\hline 11 & Dibenzo-thiophene & $\mathrm{C}_{12} \mathrm{H}_{8} \mathrm{~S}$ & 184.26 & 18.32 \\
\hline 12 & Phenanthrene & $\mathrm{C}_{14} \mathrm{H}_{28} \mathrm{O}_{2}$ & 228.12 & 1.44 \\
\hline 13 & Decamethylcyclopentasiloxane & $\mathrm{C}_{10} \mathrm{H}_{30} \mathrm{O}_{5} \mathrm{Si}_{5}$ & 370.77 & 11.20 \\
\hline 14 & dibutyl ester & $\mathrm{C}_{12} \mathrm{H}_{22} \mathrm{O}_{4}$ & 230.30 & 11.72 \\
\hline 15 & 2-Ethyl-1-hexanol & $\mathrm{C}_{8} \mathrm{H}_{18} \mathrm{O}$ & 130.23 & 1.09 \\
\hline 16 & 2,4-bis-(t-butyl)-methoxy Benzene & $\mathrm{C}_{16} \mathrm{H}_{26} \mathrm{O}_{2}$ & 250.38 & 1.93 \\
\hline 17 & Fluorene & $\mathrm{C}_{13} \mathrm{H}_{10}$ & 166.32 & 4.08 \\
\hline 18 & Cyclopenta (cd) pyrene & $\mathrm{C}_{18} \mathrm{H}_{10}$ & 226.28 & 10.28 \\
\hline
\end{tabular}

\section{Conclusion}

This study showed hexane as effective solvent in solubilizing the SEO for its adsorptive separation. Pretreatment with clay is significant for efficient recovery of aromatic hydrocarbons suitable as feedstock for petrochemical industries. African star apple fruit shell, a renewable agricultural waste, can appropriately serve effectively as adsorbent in combination with clay material, for separation of the spent lubricating oil. The textural analysis revealed ASA as compact adsorbent while GC-MS spectrometer served an effect instrumentation for characterizing the product of adsorption.

\section{Acknowledgements}

The authors appreciate Department of Chemical Engineering, Afe-Babalola University, Ado-Ekiti for the assistance in conducting the instrumental analysis. Also, the technical staff of the Department of Chemical Engineering of Obafemi Awolowo University, Ile-Ife in fabrication of all the experimental rigs used.

\section{References}

[1] R.R. Mohammed, et. al., Waste lubricating oil treatment by extraction and adsorption. Journal of Chemical Engineering. 220 (2013) 343-351. doi: 10.1016/j.cej.2012.12.076

[2] E. T. Cutler, Conserve lube oil: re-refine. Journal Hydrocarbon Process. 265 (2009), 234 -267.

[3] H. Izza, et al., Recycling of used motor oil as an alternative method for production feedstock for the conversion processes, Petroleum Science and Technology, 36(19) (2018)1511-1515. doi: 10.1080/10916466.2018.1458126

[4] C. Kajdas, Major pathways for used oil disposal and recycling. Part 1, Tribotest 7(1) (2006)61-74.

[5] A. Sadeek, et al., Hydro treating of waste lube oil by rejuvenated spent hydro treating catalyst. Journal of Egyptian Petroleum. 234 (2014) 0621-1110. 
[6] S. Agarry, and E. Ogunleye, Box-behnken designs application to study enhanced bioremediation of soil artificially contaminated with spent engine oil using bio stimulation strategy. International Journal of Energy and Environmental Engineering 3 (2012) 31-34.

[7] O. C. Nwinyi, O. Ajaja, and C. Nwinyi, Growth dynamics of bacteria isolated from spent engine oil contaminated tropical soil. Research Journal of Environmental and Earth Sciences. 6 (2014) 430- 436.

[8] M. M. Rahman, et al., Effect of operating variables on regeneration of base-oil from waste oil by conventional acid-clay method. Chemical Engineering Research Bulletin. 12 (2008) 24-27.

[9] H. A. Kheireddine, El-Halwagi, M.M. and Elbashir, N.O. A property-integration approach to solvent screening and conceptual design of solvent-extraction systems for recycling used lubricating oils. Clean Technology and Environmental Policy 15, 35-44 (2013). https://doi.org/10.1007/s10098-012-0482-5

[10] T. Bhaskar, et al., Recycling of waste lubricant oil into chemical feedstock or fuel oil over supported iron oxide catalysts, Journal on Fuel Analysis. 83 (2004) 9-15.

[11] E.A. Taiwo and Bello Tope, Hydro-distillation of spent lubricating oil and characterization of the product. Petroleum Science and Technology, 38(4) (2020) 345-353, DOI: $10.1080 / 10916466.2019 .1705860$

[12] H. Bridjanian and M. Sattarin, Modern recovery methods in used oil re-refining. Petroleum and Coal. 48 (1) (2006) 40-43

[13] J. D. Udonne J.D. and O. A. Bakare, Recycling of used lubricating oil using three samples of acids and clay as a method of treatment. International Archive of Applied Sciences and Technology IAAST. 4(2) (2013) 8- 14

[14] E. A. Emam and Abeer M. Shoaib, Re-refining of used lube oil by solvent extraction and vacuum distillation followed by hydro treating. Petroleum and Coal 55 (3) (2013) 179-187.

[15] J. C. O.Santos, Recovery of used lubricating oils - a brief review. Progress in Petrochemical Science, 1(4) (2018). PPS.000516.2018.

[16] A. D. Eleni, et al., Activated carbon for the removal of heavy metal ions: A systematic review of recent literature focused on lead and arsenic ions, Open Chemistry. 13 (2015), 699-708.

[17] E. A. Taiwo and S. I. Iragunima, Adsorption capacity and kinetics study of aqueous ethanol purification using Nigerian woods sawdust. Ife Journal of Technology, Nigeria. 19(1) (2010) 93-99.

[18] E. A. Taiwo and O. Adeodu, Evaluation of sawdust and sugarcane fibre as molecular sieve in adsorptive concentration of aqueous ethanol. Ife Journal of Technology, Nigeria. 20(1) (2011) $39-43$

[19] S. F Lo, et al., Adsorption capacity and removal efficiency of heavy metal ions by Moso and Ma bamboo activated carbons. Chemical Enginering Research and Design, 90 (2012) 1397 1406

[20] O. P. Akinyemi and E. A. Taiwo, Production of activated carbon from agricultural wastes. 34th Nigerian Society of Chemical Engineers Annual Conference, Nigeria 2004, pp 25-27 Nov. 2004

[21] A. N. Anozie, et al., Dehydration of ethanol-water mixture using activated carbons from sawdust and palm kernel shells. Separation Science and Technology 45(10) (2010) 1482-1489. DOI: $10.1080 / 01496391003775998$

[22] M. K. Lam and R. Zakaria, Production of activated carbon from sawdust using fluidized bed reactor. International Conference on Environment 2008 (ICENV 2008) Conference 15th to 17th December 2008. Penang, Malaysia

[23] O.S. Amuda, et al., "Steam activated carbon prepared from Chrysophyllum albidum seed shell for the adsorption of cadmium in wastewater: Kinetics, equilibrium and thermodynamic studies," International Journal of Environment and Waste Management, vol. 12(2), (2013) 213-229. 
[24] ASTM D 854-00 ASTM Standards test methods for specific gravity of solids by water pycnometer.

[25] T. E. Omoniyi, Olorunnisola A.O. Experimental Characterisation of Bagasse Biomass Material for Energy Production. International Journal of Engineering and Technology Volume 4 (10) (2014) $582-589$

[26] AOAC, (1990): Official Methods of Analysis, 14th edition. Association of Analytical Chemists, Washington D.C.

[27] A. A. Ibikunle, et al., Food Grade Carboxymethyl Cellulose Preparation from African Star Apple Seed (Chrysophyllum Albidum) Shells: Optimization and Characterization. Ife Journal of Science Vol. 21, No. 3 (2019)

[28] A.A. Olufunmilola and A. S. Oladapo, Physico-chemical properties of African star apple (Chrysophylum albidum) components. Nutrition \& Food Science, 41(1) (2011) 8-11,

[29] P. N. Ikenyiri and C. P. Ukpaka C. P., Overview on the effect of particle size on the performance of wood based adsorbent. Journal of Chemsical Engineering and Process Technology, 7(5) (2016) doi:10.4172/2157-7048.1000315

[30] Ying Zhang, et al., Characterization of -Treated Rice Husk Adsorbent and Adsorption of Copper (II) from Aqueous Solution. BioMed Research International Volume 2014, Article ID 496878, 8 pages http://dx.doi.org/10.1155/2014/496878

[31] M. Zendehdel, A. Barati, and H. Alikhani, 2011. Removal of heavy metals from aqueous solution by poly (acrylamide-co-acrylic acid) modified with porous materials. Polymer Bulletin, vol. 67, no. 2, pp. 343-360, 2011.

[32] O. B. Ajayi, Oyetayo Folake L. and Akomolafe Seun F. (2020). Starch composition, glycemic indices, antioxidant properties and carbohydrate hydrolyzing enzymes activities of African star apple fruit parts. BMC Complementary Medicine and Therapies (2020) 20:260. https://doi.org/10.1186/s12906-020-03053-9

[33] M.A. Anang, Michael Oteng-Peprah, and Kwasi Opoku-Boadu (2019). Extraction and Characterisation of African Star Apple (Chrysophyllum albidum) Seed Oil and the Adsorptive Properties of the Fruit Shell in Ghana. International Journal of Food Science Volume 2019, Article ID 4959586, 8 pages https://doi.org/10.1155/2019/4959586

[34] D. L. Bachelder, Recycling Used Engine Oil by Re-refining, Used Oil/ HHW Conference, San Diego, California, USA. 2005, pp 61-67.

[35] Gerald W. McGraw, et al., Thermal degradation of terpenes: camphene, $\delta 3$-carene, limonene, and $\alpha$-terpinene. Environ. Sci. Technol. 1999, 33 (1999) 4029-4033.

[36] Pujro Richard, Marisa Falco and Ulises Sedran, Formation of aromatics in heavy gasoline and light LCO ends in FCC. Applied Catalysis A: General. 489 (2015) 123-130. doi.org/10.1016/j.apcata.2014.09.051

[37] P. Rajendran, P. Bashpa, and K. Bijudas. Kinetic and mechanistic studies of the oxidation of naphthalene by potassium permanganate in aqueous acetic medium. Journal of Chemical and Pharmaceutical Sciences. 10(1) (2017) 198 -202

[38] J. D. Udonne, et al., Recycling used lubrication oil using untreated, activated and calcined clay methods. Journal of. Engineering and Applied Science. 11(6) (2016), 1396-1401

[39] Pujro Richard, Marisa Falco and Ulises Sedran, Catalytic cracking of heavy aromatics and polycyclic aromatic hydrocarbons over fluidized catalytic cracking catalysts. Energy Fuels. 29(3) (2015)1543-1549. doi.org/10.1021/ef502707w. 